\title{
Length-weight relationships and ponderal index of three reef fish (Teleostei: Labridae) off the Tanjung Tiram coast, Southeast Sulawesi, Indonesia
}

\author{
ASRIYANA ASRIYANA ${ }^{1,2, \vartheta}$, NUR IRAWATI ${ }^{1}$, HALILI HALILI ${ }^{1}$ \\ ${ }^{1}$ Department of Aquatic Resources Management, Faculty of Fisheries and Marine Sciences, Universitas Halu Oleo. Jl. HEA Mokodompit, Kampus \\ Bumi Tridharma Anduonohu, Kendari 93232, Southeast Sulawesi, Indonesia. Tel. +62-823-4267-8801, "email: asriyana @uho.ac.id \\ ${ }^{2}$ The Indonesian Ichthyological Society (IIS). Jl. Raya Jakarta-Bogor Km. 46, Cibinong, Bogor 16911, West Java, Indonesia
}

Manuscript received: 7 September 2019. Revision accepted: 3 March 2020.

\begin{abstract}
Asriyana A, Irawati N, Halili H. 2020. Length-weight relationships and ponderal index of three reef fish (Teleostei: Labridae) off the Tanjung Tiram coast, Southeast Sulawesi, Indonesia. Biodiversitas 21: 1279-1286. Parameters of length-weight relationship and ponderal index were estimated for first time for three reef fish (Labridae), Cheilinus trilobatus, Cheilinus chlorourus, and Choerodon anchorago, off the Tanjung Tiram coast, Indonesia. A total of 292 specimens (C. trilobatus 146 specimens; C. chlorourus 100 specimens; $C$. anchorago 46 specimens) were collected monthly in experimental gillnets in coral reefs and seagrass beds from January to June 2018. The length-weight relationship and ponderal index were calculated for each species. $C$. trilobatus showed total length and weight of 9.0-17.2 cm and 12.33-78.79 g, respectively, while C. chlorourus was 8.5-17.5 cm and 10.41-100.21 g, and C. anchorago 9.0$27.0 \mathrm{~cm}$ and $18.51-414.00$ g. C. trilobatus showed negative allometric growth, while C. chlorourus and C. anchorago had isometric growth. The length-weight relationship of $C$. trilobatus followed the linear equation of $\mathrm{W}=0.10 \mathrm{TL}^{2.35}$, while $C$. chlorourus and $C$. anchorago fit to $\mathrm{W}=0.03 \mathrm{TL}^{2.83} ; \mathrm{W}=0.03 \mathrm{TL}^{2.91}$ respectively. The highest ponderal index occurred in May for $C$. trilobatus and in June for $C$. chlorourus and $C$. anchorago indicating a peak of the spawning season. The study results could be used as baseline information for future fisheries management of the area.
\end{abstract}

Keywords: Growth pattern, isometric, Labridae, negative allometric, Southeast Asia

\section{INTRODUCTION}

Wrasses (Teleostei: Labridae) are reef-associated fishes among the dominant species in coral reefs (Meekan et al. 1995; Green 1996; Khalaf et al. 2005). Labridae is composed of at least 548 known species in 70 genera and considered as the second-highest in species diversity after Pomacentridae (Parenti and Randall 2018). Labridae is widespread along the coast of the Indian, Pacific and Atlantic Oceans (Nelson 1994; Helfman et al. 2009; Skiftesvik et al. 2014) and also represents a trophic major fish group in coral reefs (Setiawan 2010) known to clean dirt and biofouling on net in salmon commercial aquaculture (Kvenseth 1996) perform cleaning fish to control the attack of ectoparasite Lepeophtheirus salmonids (salmon lice) copepods in commercial Atlantic salmon culture (Salmo salar) and trout (Oncorhynchus mykiss) (Skiftesvik et al. 2014). Labridae is also known to have various trophic guilds and functional groups and fundamental roles in maintaining the health of coral reef systems (Cardozo-Ferreira and Joyeux 2016).

Various species of Labridae are well distributed in Indonesia's waters and are caught as by-catch in Scaridae (parrotfish) fisheries (Aswady et al. 2019, Dayuman et al. 2019). The important roles of Labridae in maintaining the health of coral reef ecosystems and fisheries require their exploitation to be regularly monitored to ensure its sustainability. One of the basic information that is currently lacking to support this management effort is about the relationship between the length-weight and the ponderal index. The length-weight relationship is very important in fisheries management since it can be to determining biomass by converting length measurements to weights, studying life history, comparing species growth between seasons and places, and assessing fish biology, physiology, ecology, and fisheries (Ricker 1975; Gonçalves et al. 1997; Moutopoulos and Stergiou 2002; Oscoz et al. 2005; Mimeche and Biche 2015). Information generated from length-weight relations can also be used to assess fish conditions and fish growth patterns, whether isometric or allometric (Zhu et al. 2008; Asriyana 2015; Hashim et al. 2017; Okomoda et al. 2018). The study of a fish population using ponderal index or condition factors is based on body length-weight analysis in which fish that is heavier with respect to its length is considered to be in healthier condition (Bolger and Connolly 1989; Asriyana et al. 2010; Asriyana 2015).

There have been studies on Labridae larvae ecology (Victor 1986); age, growth, and reproduction (Hostetter and Munroe 1993; Donaldson 1995); eco-structure and spatial distribution (Hukom 1999; Locham et al. 2010); distribution, preference, habitat, and density (Dorf and Powell 1997; Skiftesvik et al. 2014, Rahman and Syam 2015); Phylogenetic (Westneat and Alfaro 2005) and community structure (Khalaf et al. 2005). Relationships of length-weight have been calculated for $C$. trilobatus (Letourneur 1998; Kulbicki et al. 2005, Gumanao et al. 2016), C. chlorourus (Letourneur et al. 1998, Kulbicki et 
al. 2005, Gumanao et al. 2016), genera Symphodus and Pomatoschictus (Gurkan et al. 2010), for Labrus mixtus (Matić-Skoko et al. 2013), Cheilinus undulatus (Kamikawa et al. 2015), Lachnolaimus maximus (Pérez-Chacón and Aguilar- Perera 2015), C. anchorago (Gumanao et al. 2016, Palla et al. 2018). However, the research on the lengthweight relationship of Labridae family in Indonesia's reef is scarcely available, and none has been off the Tanjung Tiram coast. The objective of this study was to determine the length-weight relationships and the ponderal index of C. trilobatus Lacepede, C. chlorourus Bloch, and $C$. anchorago Bloch off the Tanjung Tiram coast, Indonesia.

\section{MATERIALS AND METHODS}

\section{Research site}

This study was conducted off the Tanjung Tiram coast, Southeast Sulawesi, Indonesia from January to June 2018

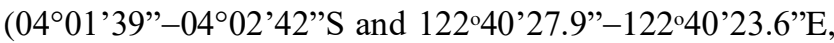
Figure 1). The number of sampling sites was determined using purposive sampling technique in the area between coral reefs and seagrass beds. The aim of purposive sampling was to collect Labridae samples that do daily migration from coral reef area to seagrass beds and vice versa.

\section{Fish collection}

Fish were captured using experimental gill nets made from nylon monofilament material of $80 \mathrm{~m}$ long; each had a different mesh size of $1,1 \frac{1}{4}, 1 \frac{1}{2}, 2$, and 3 inches. Sampling was carried out every month in the three locations. The net was set in the sea at 1.5 to $3 \mathrm{~m}$ deep during low tide and lifted at the highest level of high tide. Trapped fish were collected and identified according to Allen (1999), Carpenter and Niem (2001), Kuiter and Tanozuka (2001), Froese and Pauly (2019). All samples were kept in cool boxes for further analysis in the laboratory where samples of male and female fish were not separated. Fish were measured in total length (TL), which is the length of the fish from the front end of the head to the last end of the tail using a $1 \mathrm{~cm}$ fish gauge and the weight determined using a scale with the accuracy of $0.1 \mathrm{~g}$.

\section{Data analysis}

The length-weight relationships (LWRs) were calculated using the equation of Le Cren (1951), Tesch (1971), Ricker (1975), Froese (2006), Asriyana (2015), and Oladipo et al. (2018):

$$
W=\alpha L^{b}
$$

Where; W is weight of fish $(\mathrm{g})$; $\mathrm{L}$ is total length of fish (cm); $\mathrm{a}, \mathrm{b}$ are constants. To test whether the value of $\mathrm{b}=3$ or not, the statistical t-test was used. The value of $b \neq 3$ means that the fish has an allometric growth pattern, whereas if $b=3$ means the fish growth pattern is isometric (Sokal and Rohl 1995). The Excel Microsoft Office v.10 was used in the length-weight relationships analysis.

The ponderal index or condition factor is calculated based on the growth pattern of the length-weight relationship. If the growth pattern was isometric, then the ponderal index was calculated using the equation below (Hile 1936):

$$
K=\frac{10^{5} \times W}{L^{3}}
$$

If the growth pattern was allometric, then the relative ponderal index was calculated (Hile 1936):

$$
K_{n}=\frac{W}{a L^{b}}
$$

Where; $\mathrm{K}_{\mathrm{n}}$ is relative ponderal index; $\mathrm{K}$ is ponderal index; $\mathrm{W}$ is weight of fish $(\mathrm{g}) ; \mathrm{L}$ is total length of fish $(\mathrm{cm})$; $\mathrm{a}, \mathrm{b}$ is constant from length-weight relationship.
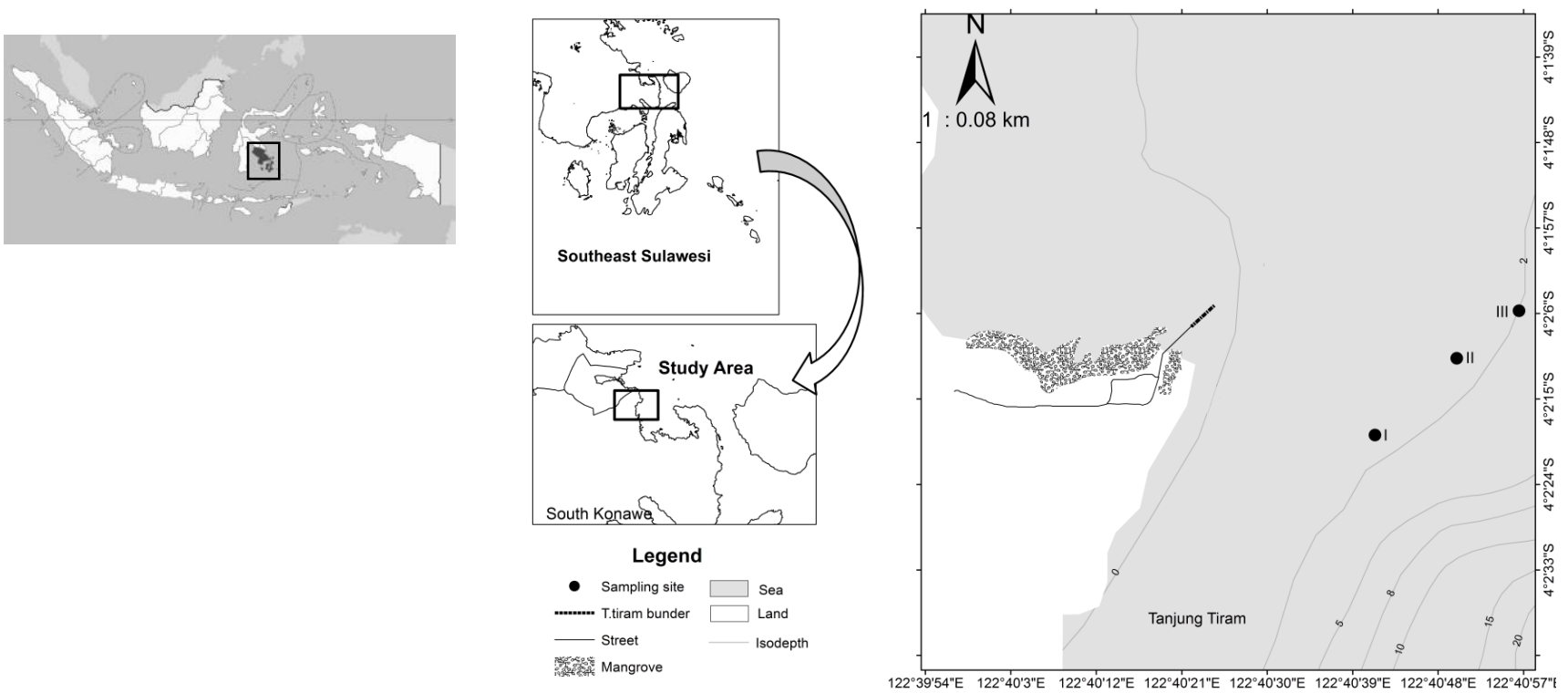

Figure 1. Map of Tanjung Tiram coast and locations of sampling stations, Southeast Sulawesi, Indonesia 
Table 1. Descriptive statistics of fish species (Labridae) from coral reefs off the Tanjung Tiram coast, Indonesia

\begin{tabular}{|c|c|c|c|c|c|c|c|c|c|}
\hline \multirow[t]{2}{*}{ Month } & \multicolumn{3}{|c|}{$\begin{array}{l}\text { Tripletail wrasse, } \\
\text { C. trilobatus Lacepede } 1801\end{array}$} & \multicolumn{3}{|c|}{$\begin{array}{l}\text { Floral wrasse, } \\
\text { C. chlorourus Bloch } 1971\end{array}$} & \multicolumn{3}{|c|}{$\begin{array}{l}\text { Orange-dotted tusk fish, } \\
\text { C. anchorago Bloch } 1791\end{array}$} \\
\hline & $\mathbf{n}$ & Length (cm) & Weight (g) & $\mathbf{N}$ & Length (cm) & Weight (g) & $\mathbf{n}$ & Length (cm) & Weight (g) \\
\hline Jan. & 26 & $9.8-12.5$ & $17.89-35.00$ & 9 & $9.5-17.5$ & $13.71-89.00$ & 1 & 14.8 & 57.74 \\
\hline Feb. & 3 & $9.9-12.0$ & $16.68-31.40$ & 45 & $8.5-17.0$ & $10.41-84.83$ & 19 & $13.0-26.2$ & $47.28-414.00$ \\
\hline Mar. & 30 & $10.9-17.2$ & $22.66-78.79$ & 19 & $10.5-16.9$ & $22.07-100.21$ & 12 & $10.8-26.1$ & $29.39-159.86$ \\
\hline Apr. & 22 & $9.0-12.5$ & $12.33-42.22$ & 6 & $10.0-15.5$ & $22.74-92.17$ & 8 & $10.0-17.6$ & $26.55-133.80$ \\
\hline May & 36 & $9.0-13.0$ & $19.32-52.92$ & 16 & $10.0-16.0$ & $31.56-91.90$ & 2 & $15.0-20.0$ & $98.01-103.22$ \\
\hline Jun. & 39 & $9.5-13.8$ & $26.51-45.32$ & 5 & $14.0-16.5$ & $65.82-91.33$ & 4 & $9.0-18.0$ & $20.31-121.22$ \\
\hline Total & 146 & $9.0-17.2$ & $12.33-78.79$ & 100 & $8.5-17.5$ & $10.41-100.21$ & 46 & $9.0-26.2$ & $20.31-414.00$ \\
\hline
\end{tabular}

Note: n: sample, Jan.: January, Feb.: February, Mar.: Maret, Apr.: April, Jun.: June

In population level, the average $\mathrm{K}$ indicates whether the population is in a better condition $(\mathrm{K}>1)$ or worse $(\mathrm{K}<1)$ than the average population (Bolger and Connolly 1989). To determine whether there were differences in the ponderal index values among the species of the Labridae family, non-parametric statistic Kruskal-Wallis with significant 0.05 (Sokal and Rohl 1995) was used using SPSS software ver. 16.0.

\section{RESULTS AND DISCUSSION}

\section{Length size distribution}

Total fish caught during the study was 292 (Table 1) where $C$. anchorago Bloch had the highest weight size compared to the other two species.

The complete frequency distributions based on the group length measurements for each species are presented in Figure 2. In $C$. trilobatus, the group with the length size range of $10.03-11.05 \mathrm{~cm}$ had the highest percentage $(27.50 \%)$ compared to the other group size ranges. In C. chlorourus, the fish group with length size between $14.37-15.54 \mathrm{~cm}$ had the highest percentage $(27.98 \%)$ while $C$. anchorago, the fish group with length size between $14.19-16.78 \mathrm{~cm}$ had the highest percentage $(41.13 \%)$.

\section{Length-weight relationship}

Based on the regression analysis, Table 2 presents the total length and weight relationship of fish collected in each month. The table shows that the Labridae family has varied growth patterns. The t-test results indicated that the growth pattern of $C$. trilobatus was negative allometric $(b<3)$, which tells that the fish length increases faster than fish weight gain. Both $C$. chlorourus and $C$. anchorago have growth pattern which indicated an isometric growth pattern $(b=3)$.

The relationship equation model of length (TL) and weight (W) of $C$. trilobatus can be represented as $\mathrm{W}=0.10$ $\mathrm{TL}^{2.35}\left(\mathrm{r}=0.88 ; \mathrm{R}^{2}=0.77\right)$. For $C$. chlorourus and $C$. anchorago, their length-weight relationship are represented with $\mathrm{W}=0.03 \mathrm{TL}^{2.84}\left(\mathrm{r}=0.95 ; \mathrm{R}^{2}=0.93\right)$ and $\mathrm{W}=$ $0.02 \mathrm{TL}^{2.94}\left(\mathrm{r}=0.93 ; \mathrm{R}^{2}=0.91\right)$, respectively.

\section{Ponderal index}

The ponderal indexes or condition factors of the three species of Labridae family found the study were varied (Figure 3). The result of the Kruskal-Wallis test revealed that there were significant differences in the ponderal index values among the three species $(\mathrm{P}<0.05 ; \alpha=5 \%, \mathrm{db}=\mathrm{n}-1)$. The ponderal index values of $C$. anchorago was higher than the other two species ranging between 0.49-4.33. The value simply that $C$. anchorago has better conditions than the other two species.

\section{Discussion}

This study has found that $C$. trilobatus and $C$. chlorourus in the waters of Tanjung Tiram have relatively higher number of individuals than C. anchorago. A similar situation was reported at Malindi Marine Park, Kenya where $C$. trilobatus and $C$. chlorourus are caught at a higher rate on fringing reefs compared to the other Labridae genera (Locham et al. 2010). This might be due to the fact that fringing reef has highest benthic algae cover (Hamilton and Brakel 1984) which provides protection from predatory compared to the habitat close to beach area. Fringing reef also provides $C$. trilobatus and $C$. chlorourus sufficient food such as mollusks, benthic crustacean, small fish, and Echinodermata (Setiawan 2010). These are the reason why the Cheilinus genera are found in a large number in this specific habitat compared with other genera.

Based on the distribution of the dominant length group (Figure 2), most of caught $C$. trilobatus, $C$. chlorourus, and $C$. anchorago were still within the juvenile stage. This is based on the report Lau and $\mathrm{Li}$ (2000), that $C$. trilobatus and $C$. anchorago in Asia-Pacific waters have a maximum length of $45 \mathrm{~cm}$ TL and $50 \mathrm{~cm}$ TL and reach gonad maturity approximately at the size of $26 \mathrm{~cm}$ TL and $23 \mathrm{~cm}$ TL, respectively. C. chlorourus found in Karimunjawa, Indonesia is reported to have a maximum size of $45 \mathrm{~cm} \mathrm{TL}$ (Setiawan 2010) and reaches gonad maturity at $19.8 \mathrm{~cm} \mathrm{TL}$ (May and Robinson 2005; Clements et al. 2012). Based on that, the size range juvenile of $C$. trilobatus, $C$. chlorourus, and $C$. anchorago in Tanjung Tiram waters were 9.0-17.2 $\mathrm{cm}$ TL, $8.5-17.5 \mathrm{~cm}$ TL, and 9.0-26.2 cm TL, respectively. 


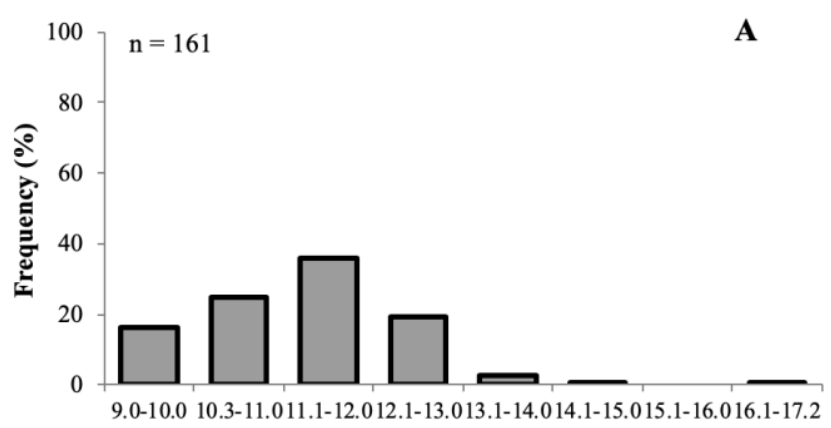

Class sixe (cm)

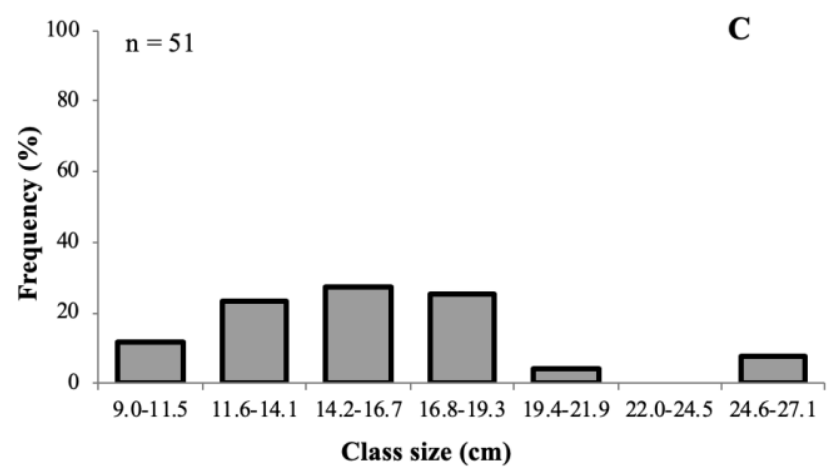

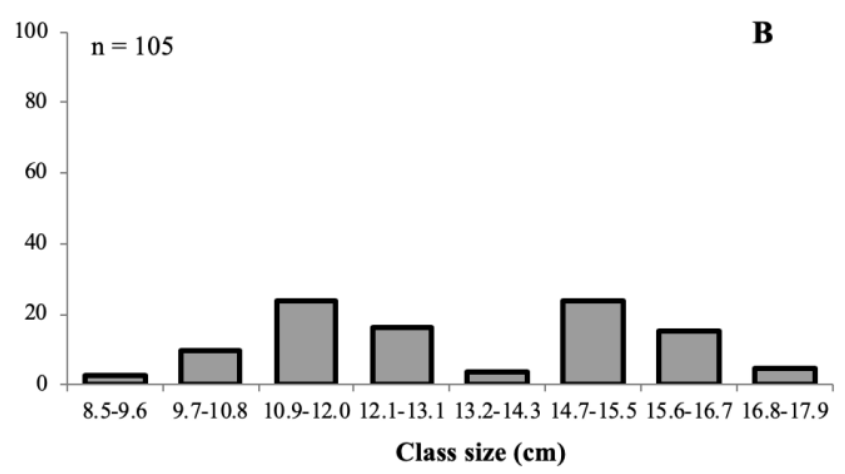

Class size (cm)

Figure 2. Size-frequency distributions of three species of Labridae: A. C. trilobatus Lacepede; B. C. chlorourus Bloch; C. C. anchorago Bloch

Most studies regarding length-weights relationships are limited to certain species of Labridae (Matic-Skoko et al. 2013; Kamikawa et al. 2015; Cardozo-Ferreira and Joyeux 2016) in which $C$. trilobatus, $C$. chlorourus, and $C$. anchorago have never been studied in Indonesia. This study provides baseline information for the three species of Labridae. This study has revealed that $C$. trilobatus has a faster increase in length compared to weight gain $(b<3)$, while $C$. chlorourus and $C$. anchorago has a proportional length to weight increase $(b=3)$ (Tabel 2). Furthermore, there is a high correlation between length and weights in the three species of Labridae ( $r \geq 0.85)$, which can be used to convert length to weight. The negative allometric growth patterns observed in $C$. trilobatus might be attributed to the moderately damaged coral reefs in the study sites with coral reef coverage of only $15-30 \%$ (University Halu Oleo Research Center-UHO RC 2011). The degraded coral reef condition in this area has limited the supply of food for the species resulting in a low body weight gain. However, the negative allometric observed in the species could also be caused by the condition of the species which was in the juvenile stage where energy requirement is mostly used for somatic growth. The relatively small number of samples might also affect the result calculation of the growth pattern.

Some studies showed that the Labridae family does not always have negative allometric and isometric growth patterns (Table 3). Growth patterns are related to the exponential values (b) of length and weight which can change. These changes are related to environmental parameters (seasonal temperature regimes) and habitat availability (Hostetter and Munroe 1993); optimal temperature, adequate food, and seasonal changes (Arslan et al. 2004, Gupta and Gupta 2006; Olopade et al. 2018); ontogenetic development (Türkmen et al. 2002); season, habitat, feeding rate, and fish health (Zhu et al. 2008); sexual dimorphism (Artigues et al. 2003); gonadal development and spawning period (Yilmaz and Polat 2009); and reproduction stage (Ouannes-Ghorbel and Bradai 2002); procedures for sampling (sample size and length range) (Ecoutin et al. 2005); parasitic pressure (Neff and Cargelli 2004); health, habitat, regional/seasonal influences, gastric fullness, samples preservation techniques, and differences in specimen size ranges (Wootton 1998; Verdiell-Cubedo et al. 2006); high dissolved oxygen concentration and circulation of water (Pathak et al. 2013). The higher the value of $b$ indicates that the environmental conditions are relatively productive (Gopakumar et al. 1991; Olopade et al. 2018).

Table 2. Length-weight relationship of three dominant species of Labridae

\begin{tabular}{lcccccl}
\hline Species & $\mathbf{n}$ & $\mathbf{a}$ & $\mathbf{b}$ & $\mathbf{r}$ & $\mathbf{R}^{2}$ & Growth pattern \\
\hline C. trilobatus & 146 & 0.10 & 2.35 & 0.88 & 0.77 Negative allometric \\
C. chlorourus & 100 & 0.03 & 2.84 & 0.95 & 0.93 & Isometric \\
C. anchorago & 46 & 0.02 & 2.94 & 0.93 & 0.91 Isometric \\
\hline Note:
\end{tabular}

Note: $\mathrm{n}=$ sample, $\mathrm{a}=$ intercept, $\mathrm{b}=$ slope, $\mathrm{r}=$ correlation, $\mathrm{R}^{2}=$ coefficient of determination 


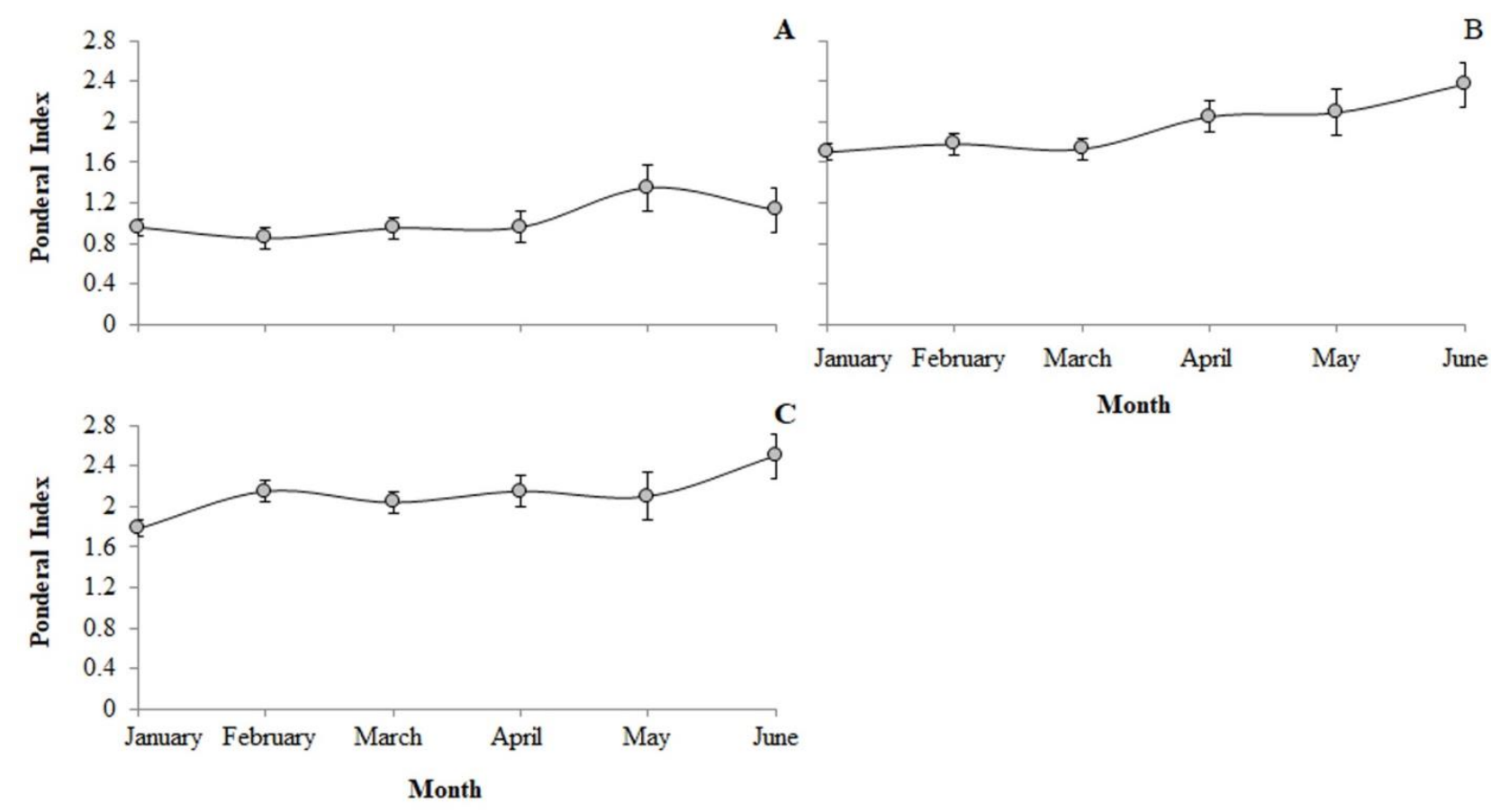

Figure 3. Ponderal index of three species of Labridae family: A. C. trilobatus Lacepede; B. C. chlorourus Bloch; C. C. anchorago Bloch

The ponderal index of the three Labridae species is varied in values (Figure 3) with the highest index occurred in May $(C$. trilobatus $\mathrm{Kn}=1.14)$ and June $(C$. Chlorourus and $C$. anchorago, each have a value of $\mathrm{K}=2.17$ ). The high ponderal index is suspected of being related to the spawning season of $C$. trilobatus. In Kimbe Bay waters of Papua New Guinea, $C$. trilobatus fish spawn between December and April during high tide (Claydon et al. 2014). The spawning information of the species is not available for Tanjung Tiram waters. The result of this study strongly indicates that $C$. trilobatus spawning occurs in May characterized by the high average of ponderal index value. Similarly, the spawning season of $C$. Chlorourus and $C$. anchorago is strongly suspected to occur in June indicated by the ponderal index value increases towards the peak of the spawning season (June) and decreases after the spawning period. During the spawning season, the increase in reproductive activity resulting in an increase in body weight and ponderal index value.

The increased of ponderal index values during reproductive activity was also reported on family Characidae at Brazil river floodplain (Lizama and Ambrósio 2002), Trachurus mediterraneus in the Aegean Sea (Tzikas et al. 2007), Johnius belangerii in Mayangan beach, Indonesia (Rahardjo and Simanjuntak 2008), Sardinella atricauda in Kendari Bay, Indonesia (Asriyana 2015), Pseudorhombus triocellatus in Parangipettai Coast, India (Bharadhirajan et al. 2019). This phenomenon can be understood as during the time of spawning, the main energy source used for gonadal development and spawning (Lizama and Ambrósio 2002) resulting in the increased values of Gonado Somatic Index (GSI) and ponderal index. High ponderal index values can also describe the conditions of reproductive activity (time and duration of gonadal maturation), abundance of food conditions in nature, and health of the aquatic ecosystem (Weatherley and Gill 1987; Abowei and Hart 2009; Ighwela et al. 2011). The somatic energy content is linearly related to the ponderal index (K) and somatic index (SI) values. In addition, GSI is positively correlated with gonadal energy. Linear trends were found between somatic parameters (K, SI, and energy content) and gonadal parameters (GSI and energy content) (Encina and GranadoLorencio 1997). Fluctuations in the values of the ponderal index every month from the three species are thought to be related to differences in fish size, food availability, time, and spawning period of $C$. trilobatus, $C$. chlorourus, and $C$. anchorago in Tanjung Tiram waters. A similar observation was reported on Barbus sclateri in the upper Guadalete River, Spain (Enchina and GranadoLorencio 1997), family Labridae along the Jordanian coast (Khalaf et al. 2005, Neff and Cargnelli 2004), Sardinella atricauda in the waters of Kendari Bay, Indonesia (Asriyana 2015).

Among the three Labridae species, $C$. anchorago had the highest ponderal index values in the range of 0.49-4.33 (mean 2.09) as the result of a greater average of body mass C. anchorago compared to the other genera (Table 1). The populations $C$. chlorourus and C. anchorago are in better condition $(\mathrm{K}>1)$ than that of $C$. trilobatus. At the population level, the $\mathrm{K}$ average indicates whether the population is in a better condition $(K>1)$ or worse $(K<1)$ than the average population (Bolger and Connolly 1989). The variations in the ponderal index values were also reported on Dicentrarchus fish labrax, Solea senegalensis, Pomatoschistus microps, and Trachurus trachurus in the Tejo Estuary waters (Duarte et al. 2018). 
Table 3. The value of the regression coefficient of the length-weight relationship of Labridae family

\begin{tabular}{lccccll}
\hline \multicolumn{1}{c}{ Species } & $\mathbf{n}$ & a value & b value & $\mathbf{R}^{\mathbf{2}}$ & \multicolumn{1}{c}{ Locations } & References \\
\hline C. chlorourus & 22 & 0.03 & 2.85 & 0.99 & Lagoon, New Caledonia & Letourneur et al. 1998 \\
C. trilobatus & 42 & 0.02 & 2.97 & 0.98 & Réunion & Letourneur 1998 \\
C. chlorourus & 44 & 0.02 & 2.99 & 0.99 & New Caledonia & Kulbicki et al. 2005 \\
C. trilobatus & 9 & 0.02 & 3.06 & 0.99 & New Caledonia & Kulbicki et al. 2005 \\
C. chlorourus & 92 & 0.04 & 2.95 & 0.97 & Davao Gulf, Philippines & Gumanao et al. 2016 \\
C. trilobatus & 133 & 0.03 & 3.04 & 0.99 & Davao Gulf, Philippines & Gumanao et al. 2016 \\
C. anchorago & 98 & 0.03 & 3.07 & 0.96 & Davao Gulf, Philippines & Gumanao et al. 2016 \\
C. anchorago & 98 & 0.02 & 3.00 & 0.99 & Palawan, Philippines & Palla et al. 2018 \\
C. trilobatus & 146 & 0.10 & 2.35 & 0.77 & Tanjung Tiram coast, Indonesia & This study 2019 \\
C. chlorourus & 100 & 0.03 & 2.84 & 0.93 & Tanjung Tiram coast, Indonesia & This study 2019 \\
C. anchorago & 46 & 0.02 & 2.94 & 0.91 & Tanjung Tiram coast, Indonesia & This study 2019 \\
\hline
\end{tabular}

Note: $n$ : sample, a: intercept, b: slope, $\mathrm{R}^{2}$ : coefficient of determination

As discussed before, the high correlation between the length and weight of the Labridae population can be used to convert length to weight. The negative allometric growth patterns in $C$. trilobatus can be associated with the damage condition of coral reef habitat classified as moderate, the condition of the species which was in the juvenile stage, and relatively small number of samples. The high ponderal index during May and June was suspected as the spawning season of the three species in the waters of Tanjung Tiram. This study recommends that to maintain the biodiversity of living organisms in general and Labridae family in particular, coral reef habitat in Tanjung Tiram has to be protected to prevent further damage and allows the ecosystem to heal itself.

\section{ACKNOWLEDGEMENTS}

We thank the undergraduate students of the Faculty of Fisheries and Marine Sciences, Halu Oleo University, Kendari, Indonesia who helped fish collection in the field and fish preparation in the laboratory; and the Faculty of Fisheries and Marine Science, Halu Oleo University for providing access to the equipment and facilities during this study.

\section{REFERENCES}

Abowei FN, Hart AI. 2009. Some morphometric parameters of 10 finfish species from the lower Nun River, Niger Delta, Nigeria. Russ J Biol Sci 4 (3): 282-288.

Allen G. 1999. A field guide for anglers and divers: Marine fishes of South East Asia. Periplus Edition (HK) Ltd. Singapore.

Arslan M, Yildirim A, Bektas S. 2004. Length-weight relationship of brown trout, Salmo trutta L. inhabiting Kan stream, Coruh Basin, North-Eastern Turkey. Turk J Fish Aquat Sci 4 (1): 45-48

Artigues B, Morales-Nin B, Balguerias E. 2003. Fish length-weight relationships in the Weddell Sea and Bransfield Strait. Polar Biol 26: 463-467.

Asriyana, Rahardjo MF, Lumban Batu DTF, Kartamihardja ES. 2010 Growth of fringe scale sardinella, Sardinella fimbriata Valenciennes (Pisces: Clupeidae) in Kendari Bay. In: Djumanto E, Chasanah HE, Irianto H, Saksono IYB, Lelana, Triyanto, Ustadi (eds). Proceedings of the Annual Seminar on Fisheries and Marine Research Results. Collaboration between UGM Faculty of Agriculture and BBRPPB Marine and Fisheries, Yogyakarta. BI-09:1-10. [Indonesian]
Asriyana. 2015. Growth and condition factor of Bleeker's blacktip sardinella, Sardinella atricauda, Gunther 1868 (Pisces: Clupeidae) in Kendari Bay, Southeast Sulawesi. Jurnal Iktiologi Indonesia 15 (1): 77-86. [Indonesian]

Aswady TU, Asriyana, Halili. 2019. Sex ratio and length maturity of parrot fish, Scarus rivulatus Valenciennes, 1840 in Tanjung Tiram of North Moramo District, South Konawe. Jurnal Manajemen Sumber Daya Perairan 4 (2): 183-190. [Indonesian]

Bharadhirajan P, Mahadevan G, Murugesan P, Murugan S, Pouladi M, Naderi RA. 2019. Relative condition factor, length-weight relationship, and growth of three-spotted flounder, Pseudorhombus triocellatus from Parangipettai Coast, India. Biodiversitas 20 (2): 373379.

Bolger T, Connolly PL. 1989. The selection of suitable indices for the measurement and analysis of fish condition. J Fish Biol 34 (2): 171182.

Cardozo-Ferreira GC, Joyeux JC. 2016. Length-weight relationships for 19 labrid species from the southern Atlantic Ocean. J Appl Ichthyol 32 (6): 1-4.

Carpenter KE, Niem VH. (eds). 1999. FAO Species Identification Guide for Fishery Purposes. The Living Marine Resources of the Western Central Pacific. Volume 6. Bony fishes part 4 (Labridae to Latimeriidae), estuarine crocodiles, sea turtles, sea snakes and marine mammals. FAO, Rome.

Claydon JAB, McCormick MI, Jones GP. 2014. Multispecies spawning sites for fishes on a low-latitude coral reef: spatial and temporal patterns. J Fish Biol 84 (4): 1136-63.

Clements CS, Bonito V, Grober-Dunsmore R, Sobey M. 2012. Effects of small, Fijian community-based marine protected areas on exploited reef fishes. Mar Ecol Prog Ser 449: 233-243.

Dayuman, Asriyana, Halili. 2019. Growth pattern and condition factors of parrot fish (Scarus rivulatus) in Tanjung Tiram of North Moramo District, South Konawe. Jurnal Manajemen Sumber Daya Perairan 4 (2): 135-143. [Indonesian]

Donaldson TJ. 1995. Courtship and spawning of nine species of wrasses (Labridae) from the Western Pacific. Jpn J Ichthyol 42 (3-4): 311 319.

Dorf BA, Powell JC. 1997. Distribution, abundance, and habitat characteristics of juvenile tautog (Tautoga onitis, Family Labridae) in Narragansett Bay, Rhode Island, 1988-1992. Coast Estuar Res Fed 20 (3): 589-600.

Duarte IA, Vasconcelos RP, França S, Batista MI, Tanner SHN, Fonseca VF. 2018. Short-term variability of fish condition and growth in estuarine and shallow coastal areas. Mar Environ Res 134: 130-137.

Ecoutin JM, Albaret JJ, Trape S. 2005. Length-weight relationships for fish populations of a relatively undisturbed tropical estuary: The Gambia. Fish Res 72 (2-3): 347-351.

Encina L, Granado-Lorencio C. 1997. Seasonal changes in condition, nutrition, gonad maturation and energy content in barbel, Barbus sclateri, inhabiting a fluctuating river. Environ Biol Fish 50 (1): 75 84.

Froese R, Pauly D. (eds). 2019. FishBase. World Wide Web electronic publication. www.fishbase.org, version (02/2019). 
Froese R. 2006. Cube law, condition factor and weight-length relationships: history, meta-analysis and recommendations. J Appl Ichthyol 22 (4): 241-253.

Gonçalves JMS, Bentes L, Lino PG, Ribeiro J, Canário AVM, Erzini K 1997. Weight-length relationships for selected fish species of the small-scale demersal fisheries of the south and southwest coast of Portugal. Fish Res 30 (3): 253-256.

Gopakumar GN, Gopalakrlshna P, Omana TA. 1991. The fishery characteristics and biology of mackerel at Vizhinjam. Mar biol Ass India 33 (1\&2): 107-114.

Green L. 1996. Spatial, temporal and ontogenetic patterns of habitat use coral reef fishes (Family Labridae). Mar Ecol Prog Ser 133: 1-11.

Gumanao GS, Saceda-Cardoza MM, Mueller B, Bos AR. 2016. Lengthweight and length-length relationships of 139 Indo-Pacific fish species (Teleostei) from the Davao Gulf, Philippines. J Appl Ichthyo 33 (2): 377-385.

Gupta SK, Gupta PC. 2006. General and Applied Ichthyology. S Chand and Co. Ltd., New Delhi.

Gurkan S, Bayhan B, Akcİnar SC, Taskavak E. 2010. Length-weigh relationship of fish from shallow waters of Candarli Bay (north Aegean Sea, Turkey). Pak J Zool 42 (4): 495-498

Hamilton GH, Brakel WH. 1984. Structure and coral fauna of East African Reef. Bull Mar Sci 34 (2): 248-266.

Hashim M, Abidin DAZ, Das SK, Mazlan AG. 2017. Length-weigh relationship, condition factor and TROPH of Scatophagus argus in Malaysian coastal waters. AACL Bioflux 10 (2): 297-307.

Helfman GS, Collette BB, Facey DE, Bowen BW. 2009. The Diversity of Fishes: Biology, Evolution, and Ecology. John Wiley \& Sons Ltd, Chichester, UK.

Hile R. 1936. Age and growth of the cisco, Leucichthys artedi Le Sueur, in the lakes of the Northeastern Highlands, Wisconsin. Bull Bureau Fisheries 48 (19): 211-317.

Hostetter EB, Munroe TA. 1993. Age, growth, and reproduction of tautog Tautoga onitis (Labridae: Perciformes) from coastal waters of Virginia. Fish Bull 91 (1): 45-64.

Hukom FD. 1999. The structure and spatial distribution of reef fish (Labridae Family) in Ambon Bay. Proceedings of the Indonesian Coral Reef Science and Technology Management Workshop, Jakarta 22-23 November 1999. [Indonesian]

Ighwela A, Ahmed B, Abol-Munafi B. 2011. Condition factor as an indicator of growth and feeding intensity of Nile Tilapia fingerlings (Oreochromis niloticus) fed on different levels of Maltose. Am Eurasian J Sustain 11 (4): 559-563.

Kamikawa KT, Cruz E, Essington TE, Hospital J, Brodziak JKT, Branch TA. 2015. Length-weight relationships for 85 fish species from Guam. J Appl Ichthyol 31 (6): 1171-1174.

Khalaf MA, Al-Horani F, Manasrah R, Al-Rousan S. 2005. Community structure of the family Labridae along the Jordanian Coast, Gulf Of Aqaba, Red Sea. Lebanese Sci J 6 (2): 1-16.

Kuiter RH, Tanozuka T. 2001. Indonesia Reef Fishes. Zoonetics PO Box 124 Seaford VIC 3198, Australia.

Kulbicki M, Guillemot N, Amand M. 2005. A general approach to lengthweight relationships for New Caledonian lagoon fishes. Cybium 29 (3): $235-252$.

Kvenseth PG. 1996. Large-scale use of wrasse to control sea lice and net fouling in salmon farms in Norway. In: Sayer IMD, Treasurer JW, Costello MJ (eds.). Wrasse: Biology and Use in Aquaculture (ss. 196203). Blackwell Science Ltd., Oxford.

Lau PPF, Li LWH. 2000. Identification Guide to Fishes in the Live Seafood Trade of the Asia-Pacific Region. World Wide Fund for Nature, Hong Kong.

Le Cren ED. 1951. The length-weight relationship and seasonal cycle in gonad weight and condition in the perch Perca fluviatilis. J Anim Ecol 20 (2): 210-219.

Letourneur Y, Kulbicki M, Labrosse P. 1998. Length-weight relationships of fish from coral reefs and lagoons of New Caledonia, southwestern Pacific Ocean: an update. Naga ICLARM Q 21 (4): 39-46.

Letourneur Y. 1998. First length-weight relationships of some marine fish species of Réunion Island, SW Indian Ocean. Naga ICLARM Q 21 (4): 37-39.

Lizama M, De Los AP, Ambrósio AM. 2002. Condition factor in nine species of fish of the Characidae family in the upper parana river floodplain, Brazil. Braz J Biol 62 (1): 113-124.

Locham GA, Kaunda-Arara B, Mlewa CM. 2010. The influence of reef type and seasonality on population structure of coral-reef fishes within Malindi Marine Park, Kenya. Mar Ecol 31 (3): 494-505.
Matić-Skoko S, Varezić DB, Šiljić J, Tutman P, Pallaoro A. 2013. The cuckoo wrasse, Labrus mixtus (Pisces: Labridae): biological indices for life history and conservation. Sci Mar 77 (4): 595-605.

May D, Robinson G. 2005. Kaledupa fisheries pilot project 2005: An Assessment of the Fisheries of Kaledupa. Operation Wallacea Trust Indonesia.

Meekan MG, Steven ADL, Fortin MJ. 1995. Spatial patterns in the distribution of damselfishes on a fringing coral reef. Coral Reefs 14 (3): 151-161

Mimeche F, Biche M. 2015. Length-weight relationships of four nonnative cyprinids from the semiarid region in North-East of Algeria. AACL Bioflux 8 (1): 82-88.

Moutopoulos DK, Stergiou KI. 2002. Length-weight and length-length relationships of fish species from Aegean Sea (Greece). J Appl Ichthyol 18 (3): 200-203.

Neff BD, Cargnelli LM. 2004. Relationships between condition factors, parasite load and paternity in bluegill sunfish, Lepomis macrochirus. Environ Biol Fishes 71 (3): 297-304

Nelson JS. 1994. Fishes of the World, $3^{\text {rd }}$ ed. John Wiley \& Sons Inc., New York.

Okomoda VT, Koh ICC, Hassan A, Amornsakun T, Shahreza SM. 2018. Length-weight relationship and condition factor of the progenies of pure and reciprocal crosses of Pangasianodon hypophthalmus and Clarias gariepinus. AACL Bioflux 11 (4): 980-987.

Oladipo SO, Nneji LM, Anifowoshe AT, Nneji IC, Iyiola OA, Adeola AC, Mustapha MK. 2018. Growth pattern and condition factor of seven freshwater fish species from Jebba Lake, north-central Nigeria. Iran J Ichthyol 5 (2): 167-172.

Olopade OA, Dienye HE, Eyekpegha A. 2018. Length frequency distribution, length-weight relationship and condition factor of cichlid fishes (Teleostei: Cichlidae) from the New Calabar River, Nigeria. Iran J Ichthyol 5 (1): 74-80.

Oscoz J, Campos F, Escala MC. 2005. Weight-length relationships of some fish species of the Iberian Peninsula. J Appl Ichthyol 21 (1): 7374

Ouannes-Ghorbel A, Bradai MN. 2002. Spawning period and sexual maturity of Symphodus (Crenilabrus) tinca (Labridae) in Sfax coasts (Tunisia). Cybium 26 (2): 89-92.

Palla HP, Pagliawan HB, Rodriguez EF, Cacho BSMGT, Gonzales BJ, Bonnell C, Fowler T. 2018. Length-weight relationship of marine fishes from Palawan, Philippines. The Palawan Sci 10: 17-28.

Parenti P, Randall JE. 2018. A checklist of wrasses (Labridae) and parrotfishes (Scaridae) of the world: 2017 update. J Ocean Sci Found 30: 11-27.

Pathak BC, Zahid M, Serajuddin M. 2013. Length-weight, length-length relationship of the spiny eel, Macrognathus pancalus (Hamilton 1822) sampled from Ganges and Brahmaputra river basins, India. Iran J Fish Sci 12 (1): 170-182.

Pérez-Chacón JE, Aguilar-Perera A. 2015. Length-weight and lengthlength relationships of the Hogfish, Lachnolaimus maximus, off the northern coast of the Yucatan Peninsula, Mexico. Gulf Caribb Res 26 (1): SC1-SC3.

Rahardjo MF, Simanjuntak CPH. 2008. Relationship between length weight and condition factors of tetet fish, Johnius belangerii Cuvier (Pisces: Sciaenidae) in Mayangan coastal waters, West Java. J Indones Aquat Fisheries Sci 15 (2): 135-140. [Indonesian]

Rahman A, Syam AR. 2015. Mapping of distribution and abundance of napoleon wrasse Cheilinus undulatus at Teluk Maumere, Kepulauan Sembilan and Takabonerate. Journal of Akuatika 6 (1): 49-58. [Indonesian]

Ricker WE. 1975. Computation and interpretation of biological statistics of fish populations. J Fish Res 191: 203-233

Setiawan F. 2010. Field Guide, Identification of Coral Fish and Marine Invertebrates. Wildlife Conservation Society (WCSIP), New York.

Skiftesvik AB, Durif CMF, Bjelland RM, Browman HI. 2014. Distribution snd habitat preferences of five species of Wrasse (Family Labridae) in a Norwegian fjord. ICES J Mar Sci 72 (3): 890-899.

Sokal RR, Rohlf FJ. 1995. Biometry: The Principles and Practice of Statistics in Biological Research. 3rd ed, WH Freeman and Co, New York

Tesch FW. 1971. Age and growth. In: Ricker WE (ed) Method for Assessment of Fish Production in Fresh Water. Blackwell Scientific Publication, Oxford.

Türkmen M, Erdoğan O, Yildirim A, Akyurt I. 2002. Reproductive tactics, age and growth of Capoeta capoeta umbla Heckel 1843 from 
the Aşkale Region of the Karasu River, Turkey. Fish Res 54 (3): 317328.

Tzikas Z, Ambrosiadis I, Soultos N, Georgakis S. 2007. Seasonal size distribution, condition status and muscle yield of Mediterranean horse mackerel Trachurus mediterraneus from the North Aegean Sea, Greece. Fisheries Sci 73 (2): 453-462.

UHO Research Center. 2011. Master Plan for Minapolitan Development for South Konawe Regency. Final Report. Research cooperation between BAPPEDA and Halu Oleo University Research Institute, Kendari. [Indonesian]

Verdiell-Cubedo D, Oliva-Paterna FJ, Torralva M. 2006. Length-weigh relationships for 22 fish species of the Mar Menor coastal lagoon (western Mediterranean Sea). J Appl Ichthyol 22 (4): 293-294.

Victor BC. 1986. Duration of the planktonic larval stage of one hundred species of Pacific and Atlantic wrasses (family Labridae). Mar Biol 90 (3): 317-326
Weatherley AH, Gill HS. 1987. The Biology of Fish Growth. Academic Press, New York.

Westneat MW, Alfaro ME. 2005. Phylogenetic relationships and evolutionary history of the reef fish family Labridae. Mol Phylogenet Evol 36: 370-390.

Wootton RJ. 1998. Ecology of Teleost Fishes. Kluwer Academic Publishers, London,

Yilmaz S, Polat N. 2009. Length-weight relations of Anatolian khramulya, Capoeta tinca (Actinopterygii: Cypriniformes: Cyprinidae), from Samsun Province, Northern Turkey. Acta Ichthyol Piscat 39 (1): 3941.

Zhu G, Xu L, Zhou Y, Dai X. 2008. Length-frequency compositions and weight-length relations for bigeye tuna, yellowfin tuna, and albacore (Perciformes: Scombridae) in the Atlantic, Indian, and Eastern Pacific Oceans. Acta Ichthyol Piscat 38 (2): 157-161. 